\title{
Article
}

\section{Design, Synthesis and Molecular Docking Study of Novel 3-Phenyl- $\beta$-Alanine-Based Oxadiazole Analogues as Potent Carbonic Anhydrase II Inhibitors}

\author{
Kashif Rafiq ${ }^{1,2}$, Najeeb Ur Rehman ${ }^{1, * \mathbb{D}}$, Sobia Ahsan Halim ${ }^{1}$, Majid Khan ${ }^{1,3} \mathbb{D}$, Ajmal Khan ${ }^{1}$ \\ and Ahmed Al-Harrasi ${ }^{1, *(D)}$
}

1 Natural and Medical Sciences Research Center, University of Nizwa, P.O Box 33, Birkat Al Mauz, Nizwa 616, Oman; kashifrafiq@unizwa.edu.om (K.R.); sobia_halim@unizwa.edu.om (S.A.H.); majidk166@yahoo.com (M.K.); ajmalkhan@unizwa.edu.om (A.K.)

2 Department of Chemistry, Abdul Wali Khan University Mardan, Mardan 23200, Pakistan

3 H. E. J. Research Institute of Chemistry, International Center for Chemical and Biological Sciences, University of Karachi, Karachi 75270, Pakistan

* Correspondence: najeeb@unizwa.edu.om (N.U.R.); aharrasi@unizwa.edu.om (A.A.-H.); Tel.: +968-2544-6328 (A.A.-H.); Fax: +968-2544-6612 (A.A.-H.)

Citation: Rafiq, K.; Ur Rehman, N.; Halim, S.A.; Khan, M.; Khan, A.;

Al-Harrasi, A. Design, Synthesis and Molecular Docking Study of Novel 3-Phenyl- $\beta$-Alanine-Based Oxadiazole Analogues as Potent Carbonic Anhydrase II Inhibitors. Molecules 2022, 27, 816 .

https://doi.org/10.3390/ molecules27030816

Academic Editors: Athina Geronikaki and Jean-Yves Winum

Received: 26 December 2021

Accepted: 24 January 2022

Published: 26 January 2022

Publisher's Note: MDPI stays neutral with regard to jurisdictional claims in published maps and institutional affiliations.

Copyright: (C) 2022 by the authors. Licensee MDPI, Basel, Switzerland. This article is an open access article distributed under the terms and conditions of the Creative Commons Attribution (CC BY) license (https:// creativecommons.org/licenses/by/ $4.0 /)$.

\begin{abstract}
Carbonic anhydrase-II (CA-II) is strongly related with gastric, glaucoma, tumors, malignant brain, renal and pancreatic carcinomas and is mainly involved in the regulation of the bicarbonate concentration in the eyes. With an aim to develop novel heterocyclic hybrids as potent enzyme inhibitors, we synthesized a series of twelve novel 3-phenyl- $\beta$-alanine 1,3,4-oxadiazole hybrids (4a-1), characterized by ${ }^{1} \mathrm{H}$ - and ${ }^{13} \mathrm{C}-\mathrm{NMR}$ with the support of HRESIMS, and evaluated for their inhibitory activity against CA-II. The CA-II inhibition results clearly indicated that the 3 -phenyl- $\beta$-alanine 1,3,4-oxadiazole derivatives $\mathbf{4 a - 1}$ exhibited selective inhibition against CA-II. All the compounds (except $4 \mathbf{d}$ ) exhibited good to moderate CA-II inhibitory activities with $\mathrm{IC}_{50}$ value in range of 12.1 to $53.6 \mu \mathrm{M}$. Among all the compounds, $4 \mathrm{a}(12.1 \pm 0.86 \mu \mathrm{M}), 4 \mathrm{c}(13.8 \pm 0.64 \mu \mathrm{M}), 4 \mathrm{~b}(19.1 \pm 0.88 \mu \mathrm{M})$ and $4 \mathrm{~h}(20.7 \pm 1.13 \mu \mathrm{M})$ are the most active hybrids against carbonic CA-II. Moreover, molecular docking was performed to understand the putative binding mode of the active compounds. The docking results indicates that these compounds block the biological activity of CA-II by nicely fitting at the entrance of the active site of CA-II. These compounds specifically mediating hydrogen bonding with Thr199, Thr200, Gln92 of CA-II.
\end{abstract}

Keywords: 3 -phenyl- $\beta$-alanine 1,3,4-oxadiazole hybrids; carbonic anhydrase-II; $\alpha$-glucosidase; structure-activity relationship; molecular docking

\section{Introduction}

Carbonic anhydrases (CAs, EC 4.2.1.1) are a class of well-studied metalloenzymes widely distributed in living organisms [1]. These are strongly involved in regulating cell homeostasis, intracellular $\mathrm{pH}$, fluid secretion, ion transport and biosynthetic reactions by catalyzing the reversible hydration of carbon dioxide $\left(\mathrm{CO}_{2}\right)$ to bicarbonate ion $\left(\mathrm{HCO}^{3-}\right)$ and proton $\left(\mathrm{H}^{+}\right)$[2-7]. This simple reaction is crucial for many physiological mechanisms including electrolyte secretion, acid-base tuning, tumorigenesis, respiration, bone resorption, calcification and biosynthesis of important molecules such as glucose, urea, and lipids [8,9]. These enzymes are common in almost all organisms from simple to complex [10,11]. The extracellular $\mathrm{pH}$ in tumors is more acidic than intracellular $\mathrm{pH}$ [11]. To generate the $\mathrm{pH}$ gradient between the extracellular and intracellular compartments, tumor cells express ion transport proteins and CA enzymes [12-14]. The CA-II is expressed in malignant brain tumors [15-17], renal cancer cell lines, and gastric and pancreatic carcinomas [15,17]. CA-II has also been used since long time for the treatment of glaucoma, epilepsy, leukemia, 
and cystic fibrosis $[18,19]$. It is remarkable that ubiquitous hCA-I and II are the main off-target isoforms because these are involved in many physiological and biochemical processes [20]. Due to the key role of this enzyme in several diseases, its inhibition is considered therapeutically important.

Oxadiazoles are heterocyclic compounds which have a diversity of useful biological effects including antibacterial [21], antifungal [22], analgesic [23], anti-inflammatory [24], antiviral [25], anticancer [26], antihypertensive [27], anticonvulsant [28] and anti-diabetic [29]. 1,3,4-Oxadiazole nucleus is present in the molecules of drugs such as: furamizole (antibacterial), tiodazosin (an $\alpha-1$ adrenergic antagonist), nesapidil (antihypertensive), raltegravir (antiretroviral), and zibotentan (anticancer) (Figure 1) [30]. The most commonly used synthetic route for the synthesis of 1,3,4-oxadiazoles includes the reactions of acid hydrazides with acid chlorides, carboxaldehyde, carboxylic acids and cyclization of the formed acylhydrazines using a dehydrating agent, such as phosphorous pentaoxide, thionyl chloride, or phosphorous oxychloride [31]. On the other hand, 1,3,4-oxadiazoles are thermally stable and neutral heteroaromatic compounds containing two nitrogens and one oxygen atom, affects the pharmacokinetic and physicochemical properties of the compounds in which it is present [32]. It makes diverse noncovalent interactions with various active sites of enzymes and receptors in biological systems and, thus display versatile pharmacological activities like anti-inflammatory [33], antidepressant [34], anti-proliferative [35], analgesic [36] and antiviral effect $[32,37,38]$.<smiles>COc1cc2nc(N3CCN(C(=O)c4nnc(SC)o4)CC3)nc(N)c2cc1OC</smiles><smiles>COc1ccccc1N1CCN(C(O)COc2cccc(-c3nnc(C)o3)c2)CC1</smiles><smiles>Cc1ccc(C(=Cc2ccc([N+](=O)[O-])o2)c2ccco2)o1</smiles>

Figure 1. Some reported 1,3,4-oxadiazole derivative drugs.

Previously, Vats et al. have synthesized novel 4-functionalized 1,5-diaryl-1,2,3-triazoles containing benzenesulfonamide moiety as carbonic anhydrase I, II, IV and IX inhibitors [39], while novel benzenesulfonamides bearing 1,2,3-triazole linked hydroxy trifluoromethylpyrazolines and hydrazones as selective carbonic anhydrase isoforms IX and XII inhibitors were reported by Sharma et al. [40]. Similarly, Kumar et al. described that the synthesis of novel benzenesulfonamide containing 1,2,3-triazoles [41] and benzenesulphonamidebearing 1,4,5-trisubstituted-1,2,3-triazoles [42] showed potent inhibition against human carbonic anhydrase isoforms I, II, IV and IX inhibitors. Bianco et al. have successfully been synthesized N-acylbenzenesulphonamide dihydro-1,3,4-oxadiazole hybrids against hCA IX and XII [43]. Recently, Sharma et al. have reported the novel benzenesulfonamides incorporating 1,3,4-oxadiazole hybrids as potent inhibitor of carbonic anhydrase I, II, IX, and XII isoenzymes [44], while Swain et al., have efficiently been synthesized have efficiently been synthesized benzenesulphonamide based 1,3,4-oxadiazoles as selective carbonic anhydrase XIII inhibitors [45]. Our group recently reported a novel class of CAs inhibitors belonging to the $1 \mathrm{H}-1,2,3$-triazole derivatives $[46,47]$. 
Our focus was on the identification of novel drug-like compounds against CA-II enzyme to combat CA-II related disorders. Keeping in mind the importance of these scaffolds in the present work, we designed and synthesized a series of novel 3-phenyl$\beta$-alanine 1,3,4-oxadiazole hybrids $4 \mathbf{a}-\mathbf{1}$ with the oxadiazole ring offering an important pharmacophore. With the hope to obtain an effective carbonic anhydrase II enzyme inhibitors, we planned to synthesize new compounds, characterized by spectroscopic techniques including ${ }^{1} \mathrm{H}-,{ }^{13} \mathrm{C}-\mathrm{NMR}$ and HRMS, and to explore their carbonic anhydrase enzyme inhibition. Later, computational docking method was applied to investigate the mode of binding of these compounds in the active site of CA-II.

\section{Results and Discussion}

\subsection{Chemistry}

The interest in finding an effective carbonic anhydrase II enzyme inhibitor has been increased in recent decades, especially with the exploring of possible relationships between carbonic anhydrase II and cancer [48-50]. CA is present in human (h) with sixteen (16) different isoforms identified from hCA I-hCA XV. All these isoforms are widely dispersed in different tissues/organs and are associated with a range of pivotal physiological activities. Due to their involvement in various physiological roles, inhibitors of different human isoforms of CA have found clinical applications for the treatment of various diseases including glaucoma, retinopathy, epilepsy, hemolytic anemia, and obesity [51]. However, clinically used inhibitors of CA (acetazolamide, brinzolamide, dorzolamide, etc.) are not selective causing the undesirable side effects. Recently we have investigated the interaction of CA-II isozymes with several types of natural and synthetic compounds $[46,47,52,53]$. Furthermore, 1,3,4-oxadiazole derivatives were found to be strong inhibitors against carbonic anhydrase II enzyme [39-42,44]. Inspired by these advances, we sought to investigate the application of this reagent in oxadiazole synthesis.

Molecular iodine plays an important role in organic synthesis, owing to its commercial availability, low cost, and low toxicity $[54,55]$. Recently, it has been successfully employed to synthesize indole derivatives [56,57] and oxazoles [58-60]. Compound 1 was synthesized through esterification of 3-phenyl- $\beta$-alanine in methanol $(\mathrm{MeOH})$ by adding thionyl chloride, followed by protection of the amino group as tert-butyloxycarbonyl (Boc), which is then treated with hydrazine in the presence of $\mathrm{MeOH}$ at room temperature Scheme 1).

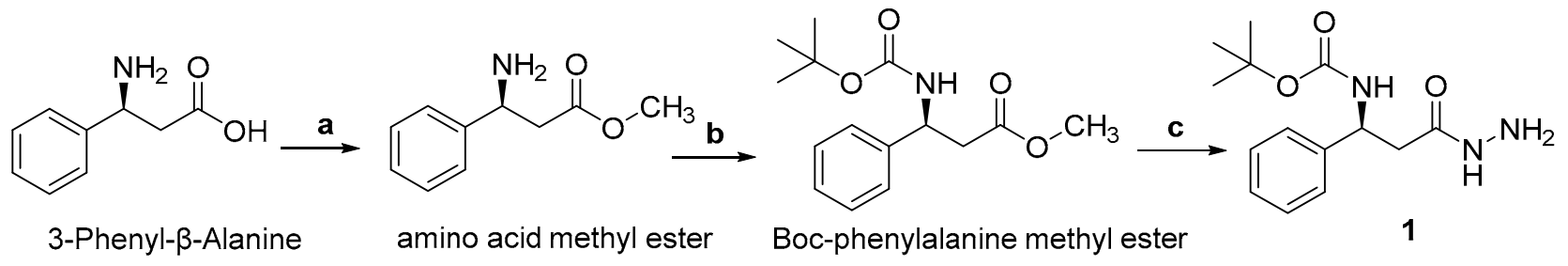

Scheme 1. Reagents and conditions: (a) $\mathrm{SOCl}_{2}, \mathrm{MeOH}, 0{ }^{\circ} \mathrm{C}$, overnight; (b) $\mathrm{NaCO}_{3}, \mathrm{H}_{2} \mathrm{O}$, Boc, EtOAc (c) $\mathrm{NH}_{2} \mathrm{NH}_{2} \cdot \mathrm{H}_{2} \mathrm{O}, \mathrm{MeOH}, \mathrm{rt}, 24 \mathrm{~h}$ (1).

Our investigation started with the cyclization of 3-phenyl- $\beta$-alanine hydrazones 3a-1 to the corresponding 1,3,4-oxadiazole $4 \mathbf{a}-\mathbf{1}$. The synthesis and NMR data of the substrates 3a-1 were already reported by our group. These compounds were prepared via the condensation of different benzaldehyde moieties $2 \mathrm{a}-\mathbf{1}(0.6 \mathrm{mmol}, 1.2$ equiv. $)$ with phenylalanine hydrazide (1, $0.5 \mathrm{mmol}, 1$ equiv.) in ethanol at refluxing temperature in $90 \%$ yield [52] (Scheme 2). The oxidative cyclization of $3 \mathbf{a}-\mathbf{1}$ to $\mathbf{4 a - 1}$ was achieved by utilizing molecular iodine in the presence of potassium carbonate $(1.8 \mathrm{mmol}, 3$ equiv. $)$ and DMSO $(2 \mathrm{~mL})$ which is the most effective media (solvent) for this conversion at $100{ }^{\circ} \mathrm{C}$. The structures of the resulting compounds were confirmed by ${ }^{1} \mathrm{H}-$ - IR, and ${ }^{13} \mathrm{C}-\mathrm{NMR}$ spectroscopy as well as mass spectrometry (HRESIMS). 
<smiles>[R]C=NNC(=O)C[C@@H](NC(=O)OC(C)(C)C)c1ccccc1</smiles>

Scheme 2. Reagents and conditions: (a) EtOH, $80{ }^{\circ} \mathrm{C}$, Reflux overnight, (3a-1, 90\%); (b) $\mathrm{K}_{2} \mathrm{CO}_{3}$, DMSO, $100{ }^{\circ} \mathrm{C}$, Reflux overnight (4a-1).

\subsection{Carbonic Anhydrase-II Enzyme Inhibition and Structural-Activity Relationship}

All the synthetic compounds reported herein, and standard carbonic anhydrase inhibitor acetazolamide were assessed for their inhibition properties towards the relevant recombinant human carbonic anhydrase-II using the colorimetric method. Most of the synthesized compounds strongly inhibited CA-II enzyme ranging from 12.1 to $53.6 \mu \mathrm{M}$. Among all, compounds $4 \mathrm{a}(12.1 \pm 0.86 \mu \mathrm{M}), 4 \mathrm{c}(13.8 \pm 0.64 \mu \mathrm{M}), 4 \mathbf{i}(18.1 \pm 1.31 \mu \mathrm{M})$, $4 \mathbf{b}(19.1 \pm 0.88 \mu \mathrm{M})$ and $4 \mathrm{~h}(20.7 \pm 1.13 \mu \mathrm{M})$ were found to be the best CA-II inhibitors, while compounds $4 \mathrm{~g}(21.5 \pm 0.99 \mu \mathrm{M}), 4 \mathbf{k}(22.4 \pm 1.32 \mu \mathrm{M}), \mathbf{4 f}(25.1 \pm 1.04 \mu \mathrm{M})$, and 4e $(26.6 \pm 0.80 \mu \mathrm{M})$ demonstrated moderate activity (Table 1). Compared to standard (acetazolamide), compound $41(53.6 \pm 0.96 \mu \mathrm{M})$ was found to be weak inhibitor against CA-II among all derivatives.

Table 1. Carbonic anhydrase-II activity of the compounds $4 \mathbf{a}-\mathbf{1}$.

Compounds


Table 1. Cont.

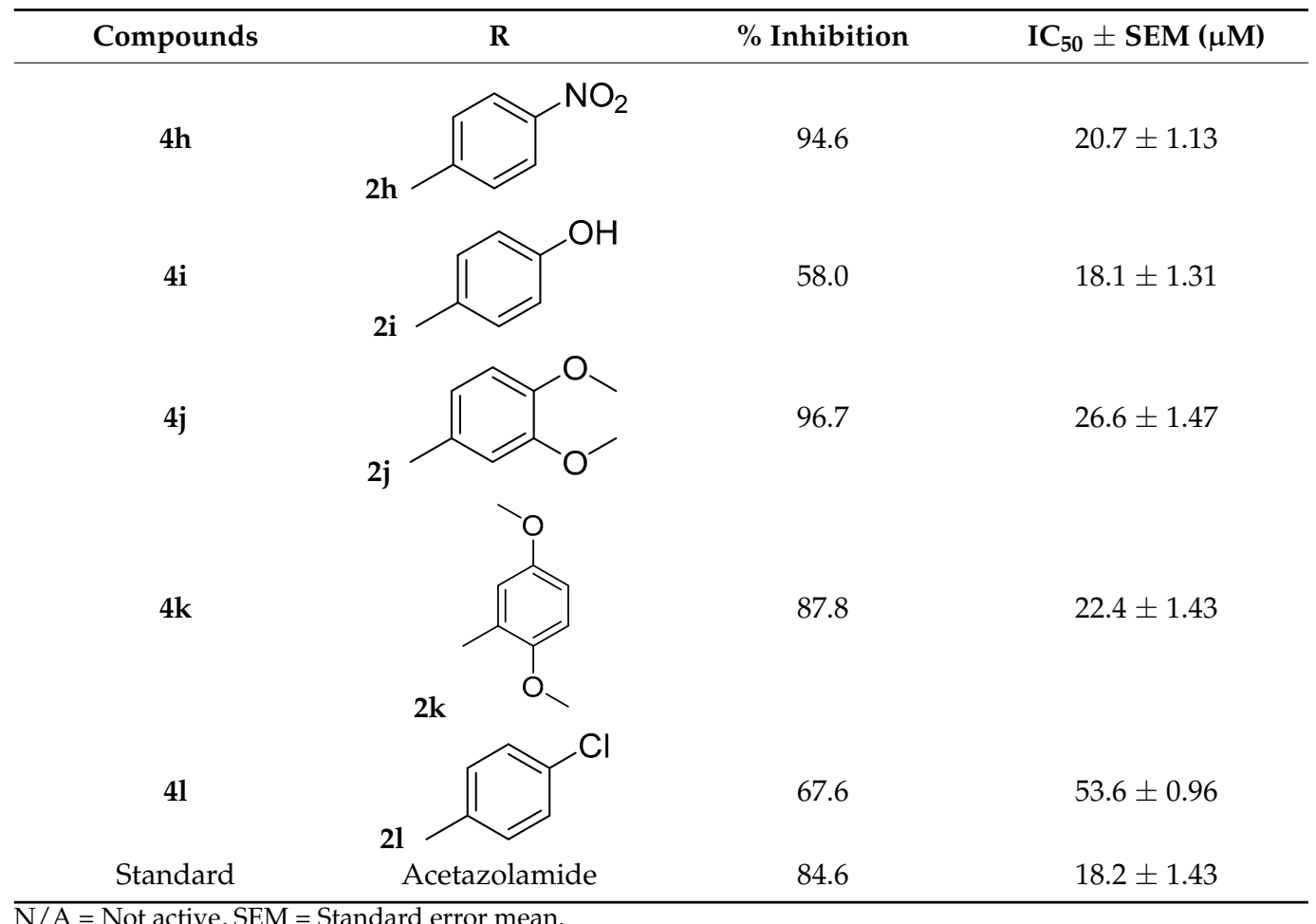

$\mathrm{N} / \mathrm{A}=$ Not active, $\mathrm{SEM}=$ Standard error mean.

Comparing compound $4 \mathbf{i}$ with $4 \mathbf{b}$, the higher activity of the $4 \mathbf{i}$ may be possible due to the presence of -OH group at para position of phenyl ring. A comparison between $4 \mathrm{~g}$ with $4 \mathrm{~h}$ revealed a slight decrease in inhibition of $\mathbf{4 g}$, which is likely due to the presence of nitro group (electron-withdrawing substituent) at ortho position of the phenyl ring. This suggests that the inhibitory activity of CA-II enzyme could be possibly increased with an electron-withdrawing substituent at para position of the phenyl ring. A slight change in activities between $\mathbf{4 j}$ and $\mathbf{4 k}$ as well as $\mathbf{4 e}$ and $\mathbf{4 f}$ was observed. The higher inhibition of $4 \mathbf{k}$ and $4 \mathbf{f}$ could be accounted for the arrangements of functional groups attached to the phenyl ring. Compound $4 \mathbf{a}\left(\mathrm{IC}_{50}=12.1 \mu \mathrm{M}\right)$ exerted a stronger inhibition than other compounds in the series, which is possibly due to the presence of pyridine ring instead of phenyl. Similarly, a higher inhibition of compound $4 \mathrm{c}$ is observed when compared with compounds $4 \mathbf{d}$ and 41 which is probably due to the absence of electron withdrawing groups at para position of the phenyl ring.

\subsection{Molecular Docking Results}

All the active compounds were docked at the active site of CA-II (PDB code: 3HS4) to predict the best possible binding modes of each active compound through molecular docking. The standard drug, acetazolamide binds at the active site and mediates several interactions including ionic interactions with $\mathrm{Zn}$ ion, hydrogen bonding with the side chains of His94, His96, Thr199 and Thr200 within the active pocket of CA-II. The binding mode of acetazolamide is shown in Figure 2. Several active compounds, including 4a, $4 \mathbf{c}$ and $4 \mathrm{i}$, exhibited CA-II inhibitory activity (in range of 12.1 to $18.1 \mu \mathrm{M}$ ) higher than the standard drug. The binding mode of the most active compound 4a depict that the carbamate moiety of the compound is involved in binding with the active site residues. Whereas oxadiazol ring and its substituted R group (pyridinyl ring) resided at the entrance of the active site. Moreover, the carbamate substituted phenyl ring was also fitted neatly in the groove near the active site entrance. The carbamate moiety of the compound mediated multiple H-bonding interaction with the amino group of Thr199 and Thr200, and side chain of Thr200. Moreover, the side chain of Gln92 also provides H-bond to the oxadiazole ring of the compound. We observed that the compound does not interact with the $\mathrm{Zn}$ ion in 
the active site, however, by interacting with several active site residues through H-bonds, and complete blockage of active site entrance, $4 \mathbf{a}$ inhibits the function of CA-II. Similar orientation was observed for compound $4 \mathbf{c}$ (the second highest active inhibitor), $\mathbf{4 i}$ and $\mathbf{4 b}$, however, carbamate moiety of these compounds interacted with the amino group and the side chain of Thr200. Additionally, -OH group at the substituted hydroxyl phenyl ring of 4b mediated H-bonding with the side chain of Gln92. The docked conformation of 4 h was completely like the binding mode of $4 \mathrm{~b}$, the carbonyl oxygen of $4 \mathrm{~h}$ binds with the amino group of Thr200, however, the oxadiazol and the substituted nitrophenyl rings did not interact with the surrounding residues. Interestingly, the carbamate and the oxadiazol ring of $\mathbf{4 g}$ do not interact with the surrounding residues, while its methoxy oxygen interacted with the amino group of Thr199 through H-bond. The substituted nitrophenyl rings of compounds $4 \mathrm{~h}$ and $4 \mathrm{~g}$ were found to be surface exposed. Similarly, the carbamate oxygen of $\mathbf{4 k}$ and $\mathbf{4 f}$ and oxadiazol ring of $\mathbf{4 f}$ formed H-bonds with the amino nitrogen of Thr200, and side chain of Gln92, respectively. The binding mode of compounds $4 \mathbf{e}$ and $\mathbf{4 j}$ demonstrated that the carbamate nitrogen of $4 \mathbf{e}$ interacted with a water molecule in the vicinity of active site, while the substituted R group mediated $\pi-\pi$ interaction with the phenyl ring of Phe131, whereas the carbonyl oxygen of $\mathbf{4} \mathbf{j}$ accepted H-bond with the amino group of Thr199. The least active compound of this series, 41 only mediates bidentate interaction with the amino nitrogen and side chain -OH of Thr200 through its carbamate moiety. The binding interactions of each compound within the active site of CA-II are tabulated in Table 2. The docked view of the most active compound $4 \mathbf{a}$ is presented in Figure 2.

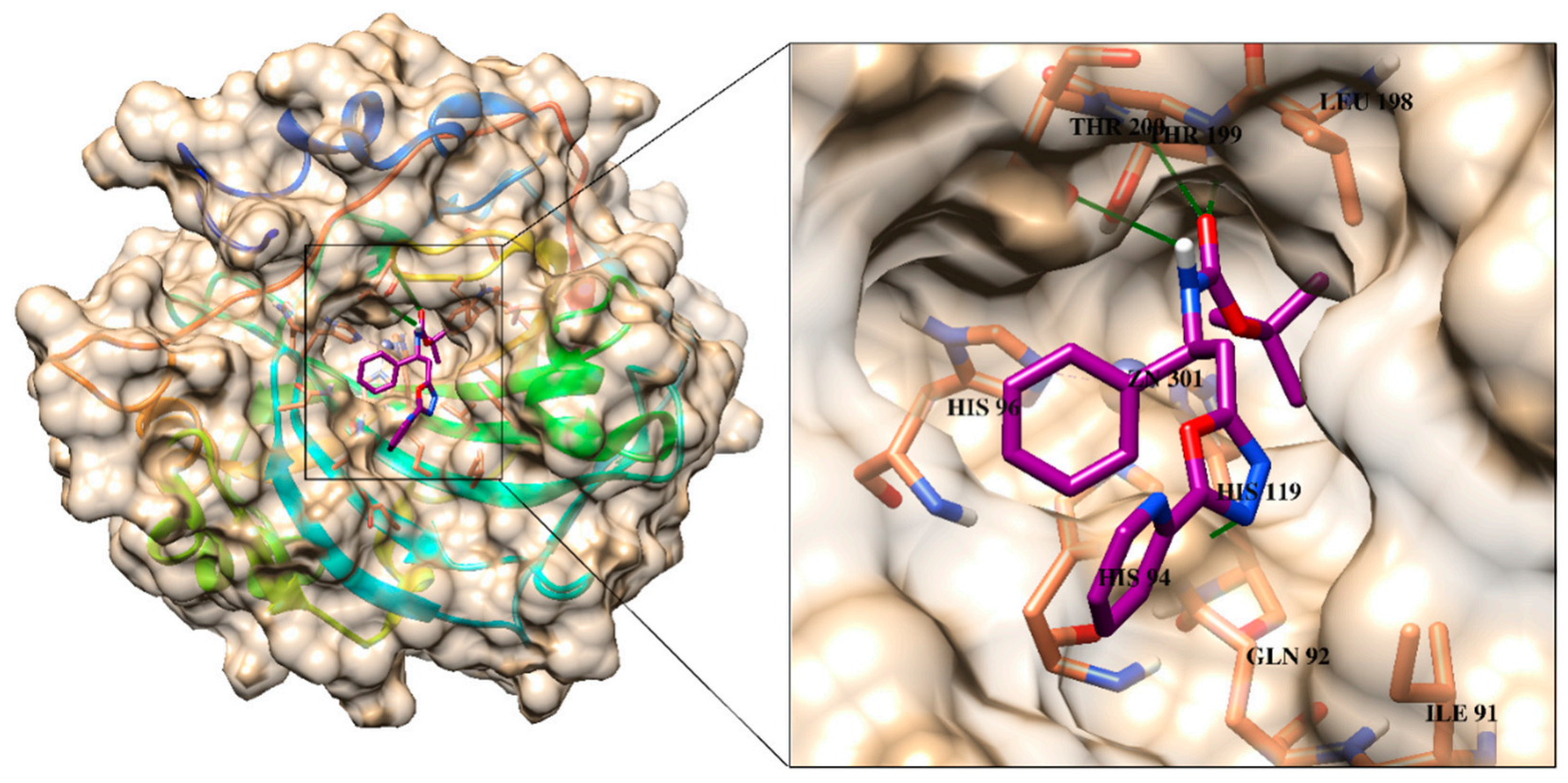

Figure 2. The binding mode of most active compound $4 \mathbf{a}$ is shown in the active site of CA-II. The ligand is presented in magenta stick model, 3D-structure of CA-II is shown in surface model, interacting residues are depicted in coral stick model and $\mathrm{H}$-bonds are presented in green lines.

The pharmacokinetic properties of the active compounds were predicted through BOILED- Egg model of SwissADME [61]. In the BOILED-Egg analysis, all the compounds showed high gastro-intestinal absorption, while none of the compounds exhibited blood brain barrier permeability. Moreover, all the compounds followed Lipinski rule of five drug-likeness criteria, and no PAIN alerts. In addition, accept $\mathbf{4 a}$, all the compounds were found as non-substrate for P-glycoprotein (Table 3). The predicted ADMET profile of the compounds suggest that these compounds could act as beneficial inhibitor of CA-II. 
Table 2. Molecular docking results of active inhibitors.

\begin{tabular}{|c|c|c|c|c|c|}
\hline \multirow{2}{*}{ Compounds } & \multirow{2}{*}{$\begin{array}{c}\text { Score } \\
\text { (kcal/mol) }\end{array}$} & \multicolumn{4}{|c|}{ Interactions } \\
\hline & & Ligand Atom & Receptor Atom & Bond Type & Distance (Å) \\
\hline \multirow{3}{*}{$4 a$} & \multirow{3}{*}{-8.96} & $\mathrm{O} 25$ & N-THR199 & HBA & 1.87 \\
\hline & & $\mathrm{O} 25$ & N-THR200 & HBA & 2.37 \\
\hline & & 6-ring & HOH-1247 & $\pi-\mathrm{H}$ & 3.53 \\
\hline \multirow{2}{*}{$4 c$} & \multirow{2}{*}{-8.2} & N22 & OG1-THR200 & HBD & 1.97 \\
\hline & & $\mathrm{O} 25$ & N-THR200 & HBA & 2.39 \\
\hline \multirow{2}{*}{$4 i$} & \multirow{2}{*}{-8.05} & N22 & OG1-THR200 & HBD & 2.95 \\
\hline & & $\mathrm{O} 25$ & N-THR200 & HBA & 2.61 \\
\hline \multirow{3}{*}{$4 b$} & \multirow{3}{*}{-7.88} & $\mathrm{O} 25$ & N-THR200 & HBA & 2.26 \\
\hline & & $\mathrm{O} 25$ & OG1-THR 200 & HBA & 1.80 \\
\hline & & 6-ring & O-HOH1247 & $\pi-\mathrm{H}$ & 3.46 \\
\hline $4 h$ & -7.63 & $\mathrm{O} 25$ & OG1-THR200 & HBA & 2.23 \\
\hline $4 \mathrm{~g}$ & -7.68 & $\mathrm{O} 26$ & N-THR199 & HBA & 1.87 \\
\hline $4 k$ & -7.80 & $\mathrm{O} 25$ & OG1-THR200 & HBA & 2.11 \\
\hline \multirow{2}{*}{$4 f$} & \multirow{2}{*}{-7.10} & $\mathrm{O} 21$ & NE2-GLN92 & HBA & 2.97 \\
\hline & & $\mathrm{O} 25$ & N-THR200 & HBA & 2.21 \\
\hline \multirow{2}{*}{$4 e$} & \multirow{2}{*}{-7.09} & N22 & O-HOH1191 & HBD & 1.99 \\
\hline & & 6-ring & 6-ring-PHE131 & $\pi-\pi$ & 3.01 \\
\hline $4 j$ & -7.10 & $\mathrm{O} 25$ & N-THR199 & HBA & 2.20 \\
\hline \multirow{2}{*}{41} & \multirow{2}{*}{-6.23} & N22 & OG1-THR200 & HBD & 1.82 \\
\hline & & $\mathrm{O} 25$ & N-THR200 & HBA & 2.08 \\
\hline
\end{tabular}

HBA $=$ Hydrogen bond acceptor, $\mathrm{HBD}=$ Hydrogen bond donor.

Table 3. The pharmacokinetic profile of active inhibitors.

\begin{tabular}{ccccccccccc}
\hline Molecule & NRB & HBA & HBD & TPSA & iLOGP & GIA & BBBP & PgpS & Lipinski V & PAINS Alerts \\
\hline $\mathbf{4 a}$ & 8 & 6 & 1 & 90.14 & 3 & High & No & Yes & 0 & 0 \\
$\mathbf{4 b}$ & 8 & 6 & 2 & 97.48 & 3.34 & High & No & No & 0 & 0 \\
$\mathbf{4 c}$ & 8 & 5 & 1 & 77.25 & 3.54 & High & No & No & 0 & 0 \\
$\mathbf{4 e}$ & 9 & 7 & 2 & 106.71 & 3.56 & High & No & No & 0 & 0 \\
$\mathbf{4 f}$ & 9 & 7 & 2 & 106.71 & 3.45 & High & No & No & 0 & 0 \\
$\mathbf{4 g}$ & 9 & 7 & 1 & 123.07 & 2.96 & High & No & No & 0 & 0 \\
$\mathbf{4 h}$ & 9 & 7 & 1 & 123.07 & 3.11 & High & No & No & 0 & 0 \\
$\mathbf{4 i}$ & 8 & 6 & 2 & 97.48 & 3.15 & High & No & No & 0 & 0 \\
$\mathbf{4 j}$ & 10 & 7 & 1 & 95.71 & 3.81 & High & No & No & 0 & 0 \\
$\mathbf{4 k}$ & 10 & 7 & 1 & 95.71 & 3.64 & High & No & No & 0 & 0 \\
$\mathbf{4 1}$ & 8 & 5 & 1 & 77.25 & 3.75 & High & No & No & 0 & 0 \\
AZM & 3 & 6 & 1 & 178.33 & 0 & Low & No & No & 0
\end{tabular}

NRB $=$ Number of rotatable bonds, HBA $=$ H-bond acceptors, $\mathrm{HBD}=\mathrm{H}$-bond donors, TPSA $=$ Topological polar surface area, GIA = Gastrointestinal absorption, BBBP = Blood brain barrier permeant, $\mathrm{PgpS}=\mathrm{P}$ glycoprotein substrate, Lipinski V = Violation of lipinski rule of 5 .

\section{Material and Methods}

\subsection{General Instrumentation}

All reagents were purchased from Sigma-Aldrich Chemical Company (St. Louis, MO, USA). Solvents used for chemical reactions were purified and dried by standard procedures. Melting point was determined using digital melting point apparatus SMP10 (Stuart ${ }^{\mathrm{TM}}$, Cole-Parmer, Beacon Rd, Stone, Staffordshire, ST15 OSA, UK). Infrared (IR) spectra were recorded on an ATR-Tensor 37 attenuated total reflectance spectrometer (Bruker, Ettlingen, Baden-Württemberg, Germany) in the range from 400 to $4000 \mathrm{~cm}^{-1}$. High-resolution electrospray ionization mass spectrometry (HR-ESI-MS, Agilent technologies, 6530, Q-TOF 
LC/MS, Agilent, country of origin USA/EU, made in Singapore) was used for the determination of compound masses. The ${ }^{1} \mathrm{H}-(600 \mathrm{MHz})$ and ${ }^{13} \mathrm{C}-(150 \mathrm{MHz}) \mathrm{NMR}$ spectra were recorded on Bruker (Zürich, Switzerland) nuclear magnetic resonance spectrometers using the solvent peak as internal reference $\left(\mathrm{CDCl}_{3}, \delta \mathrm{H}: 7.26 ; \delta \mathrm{C}: 77.2-76.8 ; \mathrm{DMSO}, \delta \mathrm{H}: 2.49\right.$; $\delta \mathrm{C}: 40.0-39.1)$. The following abbreviations were used to explain for NMR signals as $\mathrm{s}=$ singlet, $\mathrm{d}=$ doublet, $\mathrm{dd}=$ doublet of doublet, $\mathrm{t}=$ triplet, $\mathrm{m}=$ multiplet $\mathrm{J}=$ coupling constant. Chemical shifts are expressed in parts per million $(\delta)$ values and coupling constants $(J)$ are given in Hertz $(\mathrm{Hz})$. All reactions were monitored by Thin-Layer-Chromatography (TLC, Merck, Darmstadt, Germany) using pre-coated aluminum sheets (silica gel $60 \mathrm{~F}_{254}$ ). TLC plates were visualized under the UV light at 254 and $366 \mathrm{~nm}$ and by spraying with the ninhydrin reagent. Solvents for chromatography were of technical grade and distilled prior to use.

\subsection{General Procedure for the Synthesis 3-phenyl- $\beta$-alanine-1,3,4-Oxadiazoles Derivatives}

3-Phenyl- $\beta$-alanine (10 mmol, $1.65 \mathrm{~g}$ ) was used as a starting material for the synthesis of Boc-3-phenyl- $\beta$-alanine hydrazide (1). Esterification of the carboxylate group was done by the slow addition of thionyl chloride $(15 \mathrm{mmol}, 2.1 \mathrm{~mL})$ to a solution of methanol $(20 \mathrm{~mL})$ containing 3-phenyl- $\beta$-alanine at $0{ }^{\circ} \mathrm{C}$. The reaction solution was stirred for overnight $(24 \mathrm{~h}$. $)$ at room temperature, while the completion of the reaction was carefully monitored by TLC for ensuring that all amount of amino acid changed to ester. After reaction completion, the solvent $(\mathrm{MeOH})$ was evaporated under vacuum and the resultant product was filtered.

In the second step, amino acid methyl ester $(9.8 \mathrm{mmol}, 1.75 \mathrm{~g})$ was added to a solution of anhydrous $\mathrm{Na}_{2} \mathrm{CO}_{3}(1.2 \mathrm{~g}, 12 \mathrm{mmol})$ and $\mathrm{H}_{2} \mathrm{O}(40 \mathrm{~mL})$ in a $100 \mathrm{~mL}$ RB flask. Then, di-tert-butyl dicarbonate (Boc anhydride, $10 \mathrm{mmol}, 2.1 \mathrm{~g})$ was dissolved in EtoAc $(20 \mathrm{~mL})$, added to that solution and the reaction was allowed to stir for $24 \mathrm{~h}$ at room temperature. The progress of the reaction was continuously observed by TLC. When the reaction was completed, the $\mathrm{pH}$ was adjusted to 5.5 with oxalic acid and then the desired product was extracted with an organic solvent (EtOAc). The solvent was dried over anhydrous $\mathrm{MgSO}_{4}$ and evaporated under reduced pressure to obtain the corresponding Boc-phenylalanine methyl ester (91\%).

In the third step, hydrazine monohydrate $(2 \mathrm{~mL}, 32 \mathrm{mmol})$ was added to a solution of methanol $(20 \mathrm{~mL})$ containing Boc-phenylalanine methyl ester $(9.1 \mathrm{mmol}, 2.5 \mathrm{~g})$ and stirred under room temperature for $24 \mathrm{~h}$ to afford phenylalanine hydrazide (1). The reaction mixture was thoroughly checked by TLC. After reaction completion, the solvent was evaporated under reduced pressure and the product tert-butyl (S)-(3-hydrazinyl-3-oxo-1phenylpropyl) carbamate (1, yield 89\%) was washed with methanol. White powder; Yield: 86\%; m-p. 187-190 ${ }^{\circ} \mathrm{C}$; FT-IR (solid, $\mathrm{cm}^{-1}$ ): 3318, 1694, 1664, and 1580, 1362, 1260, 1160, and 1092; ${ }^{1} \mathrm{H}-\mathrm{NMR}\left(\mathrm{CDCl}_{3}\right): \delta 8.54(1 \mathrm{H}, \mathrm{s}, \mathrm{NH}), 7.30(1 \mathrm{H}, \mathrm{C}-\mathrm{NH}), 4.88\left(2 \mathrm{H}, \mathrm{NH}-\mathrm{NH}_{2}\right), 7.11-7.28$ $(5 \mathrm{H}, \mathrm{m}), 4.97(\mathrm{CH}-\mathrm{NH}), 2.93-3.14\left(2 \mathrm{H}, \mathrm{CH}_{2}\right), 1.36(9 \mathrm{H}, \mathrm{s}) ;{ }^{13} \mathrm{C}-\mathrm{NMR}\left(\mathrm{CDCl}_{3}\right): \delta 28.3,38.5$, 55.2, 79.7, 126.0, 126.6, 126.7, 128.0, 128.5, 155.3, 143.2, 155.9, 177.3; HRMS (ESI+) $m / z$ : 302.1477 [M+ Na $]^{+}$.

In the fourth step, a solution of aldehyde $(0.6 \mathrm{mmol})$ added to a stirred solution of 1 $(0.5 \mathrm{mmol})$ in $\mathrm{EtOH}(5 \mathrm{~mL})$ at room temperature for $24 \mathrm{~h}$. The progress of the reaction was monitored with TLC system of EtOAc/n-hexane (3:7). After completion of the reaction, the product (3) was filtered, washed with $n$-hexane for removing any excess of aldehyde. The resulting residue was redissolved in DMSO $(2 \mathrm{~mL})$, followed by addition of potassium carbonate $(3 \mathrm{mmol})$ and iodine $(1.2 \mathrm{mmol})$ in sequence. The reaction mixture was stirred at $100{ }^{\circ} \mathrm{C}$ until the conversion was complete ( $1-4 \mathrm{~h}$, monitored by TLC, $)$. After being cooled to room temperature, it was treated with $5 \% \mathrm{Na}_{2} \mathrm{~S}_{2} \mathrm{O}_{3}(20 \mathrm{~mL})$, extracted with EtOAc $(10 \mathrm{~mL}$, three times). The combined organic layer was washed with brine $(10 \mathrm{~mL} \times 1)$, dried over anhydrous sodium sulfate, and concentrated. The given residue was purified through preparative thin layer chromatography (TLC) using a mobile phase of EtOAc and $n$-hexane (3:7) to afford the desired oxadiazoles. All compounds were obtained in fare yields ranging 
from 57 to $64 \%$. The structures of all compounds were established by HRMS, ${ }^{1} \mathrm{H}$ - and ${ }^{13} \mathrm{C}-\mathrm{NMR}$ and same procedure was use for the synthesis of other compounds.

3.2.1. Tert-Butyl (S)-(1-phenyl-2-(5-(pyridin-2-yl)-1,3,4-oxadiazol-2-yl) ethyl) carbamate (4a)

White solid powder; Yield: 57\%; FTIR (solid, $\mathrm{cm}^{-1}$ ): 3320, 1690, 1666, and 1585, 1365, 1264,1160 , and $1094 ;{ }^{1} \mathrm{H}-\mathrm{NMR}\left(\mathrm{CDCl}_{3}\right): \delta 8.76(1 \mathrm{H}), 8.18(1 \mathrm{H}), 7.86(1 \mathrm{H}), 7.45(1 \mathrm{H}), 7.25-7.10$ $(5 \mathrm{H}, \mathrm{m}), 5.40(1 \mathrm{H}, \mathrm{NH}), 5.19(1 \mathrm{H}, \mathrm{CH}), 3.22,3.35(2 \mathrm{H}), 1.37(9 \mathrm{H}, \mathrm{s}) ;{ }^{13} \mathrm{C}-\mathrm{NMR}\left(\mathrm{CDCl}_{3}\right): \delta$ 28.2, 39.9, 48.5, 80.4, 123.2, 126.0, 127.2, 128.7, 129.4, 135.2, 137.3, 143.3, 150.3, 164.2, 167.1; HRMS $\left(\mathrm{ESI}^{+}\right) m / z: 366.1756[\mathrm{M}+\mathrm{H}]^{+}$.

3.2.2. Tert-Butyl (S)-(2-(5-(2-hydroxyphenyl)-1,3,4-oxadiazol-2-yl)-1-phenylethyl) carbamate $(\mathbf{4 b})$

Solid powder; Yield: 56\%; FTIR (solid, $\mathrm{cm}^{-1}$ ): 3318, 1689, 1670, and 1594, 1445, 1375, 1340, 1302 and $1160 ;{ }^{1} \mathrm{H}-\mathrm{NMR}\left(\mathrm{CDCl}_{3}\right): \delta 10.86(1 \mathrm{H}, \mathrm{OH}, \mathrm{s}), 8.15(1 \mathrm{H}), 7.65(1 \mathrm{H}), 7.42(1 \mathrm{H})$, $7.30(1 \mathrm{H}), 7.25-6.72(5 \mathrm{H}, \mathrm{m}), 5.36(1 \mathrm{H}, \mathrm{NH}), 5.09(1 \mathrm{H}, \mathrm{CH}), 3.29,3.28(2 \mathrm{H}), 1.41(9 \mathrm{H}, \mathrm{s})$; ${ }^{13} \mathrm{C}-\mathrm{NMR}\left(\mathrm{CDCl}_{3}\right): \delta 28.2,39.8,48.6,81.2,86.8,109.5,119.9,121.5,124.9,126.8,127.5,128.7$, 128.9, 129.3, 133.8, 134.7, 143.3, 154.8, 157.7, 165.8; HRMS (ESI $\left.{ }^{+}\right) \mathrm{m} / z: 382.1814[\mathrm{M}+\mathrm{H}]^{+}$.

3.2.3. Tert-Butyl(S)-(1-phenyl-2-(5-phenyl-1,3,4-oxadiazol-2-yl)ethyl) carbamate (4c)

Pale yellow Color; Yield: 58\%; FTIR (solid, $\mathrm{cm}^{-1}$ ): 3336, 1710, 1668, 1608, 1375, 1335, 1290 and $1080 ;{ }^{1} \mathrm{H}-\mathrm{NMR}\left(\mathrm{CDCl}_{3}, 600 \mathrm{MHz}\right): \delta 7.88-7.39(5 \mathrm{H}, \mathrm{m}), 7.22-7.07(5 \mathrm{H}, \mathrm{m}), 5.47$ $(1 \mathrm{H}, \mathrm{NH}), 5.25(1 \mathrm{H}, \mathrm{CH}), 3.23,3.20(2 \mathrm{H}), 1.33(9 \mathrm{H}, \mathrm{s}) ;{ }^{13} \mathrm{C}-\mathrm{NMR}\left(150 \mathrm{MHz}, \mathrm{CDCl}_{3}\right): \delta 28.2$, 29.6, 48.5, 80.3, 123.6, 126.8, 127.1, 128.6, 129.0, 132.9, 131.7, 135.6, 154.9, 164.9, 166.2; HRMS $\left(\mathrm{ESI}^{+}\right) \mathrm{m} / z: 366.1948[\mathrm{M}+\mathrm{H}]^{+}$.

3.2.4. Tert-Butyl(S)-(2-(5-(4-methoxyphenyl)-1,3,4-oxadiazol-2-yl)-1-phenylethyl) carbamate (4d)

White solid powder; Yield: 57\%; FTIR (solid, $\mathrm{cm}^{-1}$ ): 3324, 1704, 1672, 1602, 1452, 1370, 1268,1160 , and $1020 ;{ }^{1} \mathrm{H}-\mathrm{NMR}\left(\mathrm{CDCl}_{3}\right): \delta 7.81(1 \mathrm{H}), 7.80(1 \mathrm{H}), 6.90(1 \mathrm{H}), 6.89(1 \mathrm{H}), 7.24-7.07$ $(5 \mathrm{H}, \mathrm{m}), 5.47(1 \mathrm{H}, \mathrm{NH}), 5.22(1 \mathrm{H}, \mathrm{CH}), 3.78\left(3 \mathrm{H}, \mathrm{CH}_{3}\right), 3.23,3.17(2 \mathrm{H}), 1.32(9 \mathrm{H}, \mathrm{s}) ;{ }^{13} \mathrm{C}-\mathrm{NMR}$ $\left(\mathrm{CDCl}_{3}\right): \delta 28.2,29.6,48.5,55.4,114.4,116.0,127.1,128.6,129.3,135.6,154.9,162.3,164.8$, 165.6; HRMS $\left(\mathrm{ESI}^{+}\right) \mathrm{m} / z: 396.1960[\mathrm{M}+\mathrm{H}]^{+}$.

3.2.5. Tert-Butyl(S)-(2-(5-(4-hydroxy-3-methoxyphenyl)-1,3,4-oxadiazol-2-yl)-1-phenylethyl) carbamate (4e)

Yellow powder; Yield: 56\%; FTIR (solid, $\mathrm{cm}^{-1}$ ): 3333, 1696, 1668, 1590, 1450, 1370, 1252, 1160, 1030; ${ }^{1} \mathrm{H}-\mathrm{NMR}\left(\mathrm{CDCl}_{3}\right): \delta 9.80(1 \mathrm{H}, \mathrm{OH}, \mathrm{s}), 7.63(1 \mathrm{H}), 7.51(1 \mathrm{H}), 7.25-7.11(5 \mathrm{H}$, $\mathrm{m}), 6.87(1 \mathrm{H}), 5.43(1 \mathrm{H}, \mathrm{NH}), 5.31(1 \mathrm{H}, \mathrm{CH}), 4.44\left(3 \mathrm{H}, \mathrm{OCH}_{3}\right), 3.94,3.86(2 \mathrm{H}), 1.38(9 \mathrm{H}, \mathrm{s})$; ${ }^{13} \mathrm{C}-\mathrm{NMR}\left(\mathrm{CDCl}_{3}\right): \delta 28.2,34.4,38.5,48.6,40.9,52.5,56.1,107.7,109.5,119.9,121.5,124.9$, 126.8, 128.7, 129.3, 136.5, 145.0, 155.3, 167.8, 190.8; HRMS (ESI $\left.{ }^{+}\right) \mathrm{m} / z: 436.2279[\mathrm{M}+\mathrm{H}]^{+}$.

3.2.6. Tert-Butyl(S)-(2-(5-(2-hydroxy-3-methoxyphenyl)-1,3,4-oxadiazol-2-yl)-1-phenylethyl) carbamate (4f)

Crystalline powder; Yield: 61\%; FTIR (solid, $\mathrm{cm}^{-1}$ ): 3320, 1690, 1664, 1594, 1450, 1405, 1358, 1257, 1164, and 1090; ${ }^{1} \mathrm{H}-\mathrm{NMR}\left(\mathrm{CDCl}_{3}, 600 \mathrm{MHz}\right): \delta 9.90(1 \mathrm{H}, \mathrm{OH}, \mathrm{s}), 8.17(1 \mathrm{H}), 7.93$ (1H), 7.29-7.10 (5H, m), $6.85(1 \mathrm{H}), 5.27(1 \mathrm{H}, \mathrm{NH}), 4.45(1 \mathrm{H}, \mathrm{CH}), 3.91(3 \mathrm{H}, \mathrm{OCH} 3), 3.91,3.87$ (2H), 1.37 (9H, s); 13C-NMR (150 MHz, $\left.\mathrm{CDCl}_{3}\right): \delta 28.2,34.4,38.1,56.3,113.7,114.2,117.5$, 119.5, 121.4, 124.5, 126.9, 128.4, 129.5, 136.3, 145.6, 151.1, 155.9, 167.4, 172.8, 196.6; HRMS $\left(\mathrm{ESI}^{+}\right) \mathrm{m} / z: 436.1883[\mathrm{M}+\mathrm{H}]^{+}$.

3.2.7. Tert-Butyl(S)-(2-(5-(2-nitrophenyl)-1,3,4-oxadiazol-2-yl)-1-phenylethyl) carbamate (4g)

Yellow powder; Yield: 56\%; FTIR (solid, $\mathrm{cm}^{-1}$ ): 3310, 1703, 1666, 1614, 1455, 1346, 1324, 1236, 1059; ${ }^{1} \mathrm{H}-\mathrm{NMR}\left(\mathrm{CDCl}_{3}\right): \delta 8.05(1 \mathrm{H}), 7.87(1 \mathrm{H}), 7.67(1 \mathrm{H}), 7.71(1 \mathrm{H}), 7.29-7.13$ $(5 \mathrm{H}, \mathrm{m}), 5.34(1 \mathrm{H}, \mathrm{NH}), 5.13(1 \mathrm{H}, \mathrm{CH}), 3.30,3.18(2 \mathrm{H}), 1.38(9 \mathrm{H}, \mathrm{s}) ;{ }^{13} \mathrm{C}-\mathrm{NMR}\left(\mathrm{CDCl}_{3}\right): \delta 28.2$, 
$39.8,48.4,118.7,124.8,127.3,128.7,129.4,131.9,132.6,133.3,135.0,148.1,154.8,161.8,167.3$; HRMS $\left(\mathrm{ESI}^{+}\right) \mathrm{m} / \mathrm{z}: 411.1694[\mathrm{M}+\mathrm{H}]^{+}$.

3.2.8. Tert-Butyl(S)-(2-(5-(4-nitrophenyl)-1,3,4-oxadiazol-2-yl)-1-phenylethyl) carbamate (4h)

Light yellow powder; Yield: 61\%; FTIR (solid, $\mathrm{cm}^{-1}$ ): 3322, 1701, 1664, 1610, 1430, $1365,1345,1208$, and $1163 ;{ }^{1} \mathrm{H}-\mathrm{NMR}\left(\mathrm{CDCl}_{3}\right): \delta 8.38(1 \mathrm{H}), 8.37(1 \mathrm{H}), 8.17(1 \mathrm{H}), 8.16(1 \mathrm{H})$, 7.32-7.17 (5H, m), $5.41(1 \mathrm{H}, \mathrm{NH}), 5.20(1 \mathrm{H}, \mathrm{CH}), 3.34,3.33(2 \mathrm{H}), 1.45(9 \mathrm{H}, \mathrm{s}) ;{ }^{13} \mathrm{C}-\mathrm{NMR}$ $\left(\mathrm{CDCl}_{3}\right): \delta 28.2,29.7,40.0,48.6,124.3,124.5,126.9,127.4,127.8,128.8,129.0,129.1,129.3$, 135.1, 149.7, 154.8, 163.2, 167.4; HRMS $\left(\mathrm{ESI}^{+}\right) \mathrm{m} / z: 411.1705[\mathrm{M}+\mathrm{H}]^{+}$.

3.2.9. Tert-Butyl (S)-(2-(5-(4-hydroxyphenyl)-1,3,4-oxadiazol-2-yl)-1-phenylethyl) carbamate (4i)

White solid powder; Yield: 59\%; FTIR (solid, $\mathrm{cm}^{-1}$ ): 3330, 1705, 1668, and 1608; ${ }^{1} \mathrm{H}-$ NMR $\left(\mathrm{CDCl}_{3}\right): \delta 7.78(1 \mathrm{H}), 7.77(1 \mathrm{H}), 7.26(1 \mathrm{H}), 7.20(1 \mathrm{H}), 7.12-6.86(5 \mathrm{H}, \mathrm{m}), 5.30(1 \mathrm{H}, \mathrm{NH})$, $5.16(1 \mathrm{H}, \mathrm{CH}), 3.29,3.24(2 \mathrm{H}), 1.38(9 \mathrm{H}, \mathrm{s}) ;{ }^{13} \mathrm{C}-\mathrm{NMR}\left(\mathrm{CDCl}_{3}\right): \delta 28.2,29.3,29.7,29.7,31.9$, 40.0, 48.5, 80.7, 116.0, 116.1, 127.2, 128.7, 128.9, 129.4, 135.4, 158.9, 164.9, 165.5; HRMS (ESI $\left.{ }^{+}\right)$ $m / z: 382.1463[\mathrm{M}+\mathrm{H}]^{+}$.

3.2.10. Tert-Butyl (S)-(2-(5-(3,4-dimethoxyphenyl)-1,3,4-oxadiazol-2-yl)-1-phenylethyl) carbamate $(4 \mathbf{j})$

White amorphous powder; Yield: 64\%; FTIR (solid, $\mathrm{cm}^{-1}$ ): 3326, 1701, 1670, 1595, $1420,1370,1336,1252,1208$, and 1143; ${ }^{1} \mathrm{H}-\mathrm{NMR}\left(\mathrm{CDCl}_{3}\right): \delta 7.50(1 \mathrm{H}), 7.49(1 \mathrm{H}), 7.45(1 \mathrm{H})$, 7.27-7.12 (5H, m), $6.90(1 \mathrm{H}), 5.32(1 \mathrm{H}, \mathrm{NH}), 5.18(1 \mathrm{H}, \mathrm{CH}), 3.92(6 \mathrm{H}, \mathrm{OCH}), 3.27,3.26(2 \mathrm{H})$, $1.40(9 \mathrm{H}, \mathrm{s}) ;{ }^{13} \mathrm{C}-\mathrm{NMR}(\mathrm{CDCl} 3): \delta 28.3,40.1,48.5,56.0,56.1,80.5,109.5,111.1,116.2,120.4$, $127.2,128.6,129.4,135.5,149.3,152.1,164.9,165.7$; HRMS $\left(\mathrm{ESI}^{+}\right) \mathrm{m} / z: 426.2066[\mathrm{M}+\mathrm{H}]^{+}$.

3.2.11. Tert-Butyl (S)-(2-(5-(2,5-dimethoxyphenyl)-1,3,4-oxadiazol-2-yl)-1-phenylethyl) carbamate $(4 \mathbf{k})$

Colorless solid; Yield: 61\%; FTIR (solid, $\mathrm{cm}^{-1}$ ): 3328, 1711, 1667, 1602, 1524, 1342, 1272, 1228,1155 , and 1066; ${ }^{1} \mathrm{H}-\mathrm{NMR}\left(\mathrm{CDCl}_{3}\right): \delta 7.30(1 \mathrm{H}), 7.24-7.11(5 \mathrm{H}, \mathrm{m}), 7.03(1 \mathrm{H}), 6.96(1 \mathrm{H})$, $5.36(1 \mathrm{H}, \mathrm{NH}), 5.22(1 \mathrm{H}, \mathrm{CH}), 3.86,3.78\left(6 \mathrm{H}, \mathrm{OCH}_{3}\right), 3.30,3.27(2 \mathrm{H}), 1.40(9 \mathrm{H}, \mathrm{s}) ;{ }^{13} \mathrm{C}-\mathrm{NMR}$ $\left(\mathrm{CDCl}_{3}\right): \delta 28.3,40.0,48.5,56.0,56.6,60.4,80.3,113.1,113.7,114.5,119.4,127.1,128.6,129.4$, $135.5,152.3,153.4,163.6,165.8 ; \operatorname{HRMS}_{\left(\mathrm{ESI}^{+}\right)} \mathrm{m} / z: 426.2065[\mathrm{M}+\mathrm{H}]^{+}$.

3.2.12. Tert-Butyl (S)-(2-(5-(4-chlorophenyl)-1,3,4-oxadiazol-2-yl)-1-phenylethyl) carbamate (41)

White powder; Yield: 57\%; FTIR (solid, $\mathrm{cm}^{-1}$ ): 3350, 1698, 1663, and 1603, 1532, 1336, 1266, 1224, 1172, and 1066; ${ }^{1} \mathrm{H}-\mathrm{NMR}\left(\mathrm{CDCl}_{3}\right): \delta 7.88(1 \mathrm{H}), 7.87(1 \mathrm{H}), 7.45(1 \mathrm{H}), 7.44(1 \mathrm{H})$, 7.27-7.12 (5H, m), $5.32(1 \mathrm{H}, \mathrm{NH}), 5.16(1 \mathrm{H}, \mathrm{CH}), 3.28,3.27(2 \mathrm{H}), 1.40(9 \mathrm{H}, \mathrm{s}) ;{ }^{13} \mathrm{C}-\mathrm{NMR}$ $\left(\mathrm{CDCl}_{3}\right): \delta 28.2,29.7,39.9,48.6,80.6,122.2,127.3,128.2,128.7,129.3,129.4,135.3,138.1$, 154.8; HRMS $\left(\mathrm{ESI}^{+}\right) \mathrm{m} / z: 400.1467[\mathrm{M}+\mathrm{H}]^{+}$.

\subsection{Carbonic Anhydrase II Inhibition Assay}

A total reaction volume of $200 \mu \mathrm{L}$ containing $20 \mu \mathrm{L}$ of the synthetic compounds $4 \mathrm{a}-1$ prepared in DMSO, followed by the addition of $140 \mu \mathrm{L}$ of the HEPES-tris buffer, $20 \mu \mathrm{L}$ of purified bovine erythrocyte CA-II $(0.15 \mathrm{mg} / \mathrm{mL})$ prepared in buffer, and $20 \mu \mathrm{L}$ of a solution of 4-nitrophenyl acetate [36,44]. $20 \mu \mathrm{L}$ of tested compounds were incubated with the enzyme carbonic anhydrase II (EC 4.2.1.1) for $15 \mathrm{~min}$ in 96-well flat bottom plate. The rate of product formation was monitored with the addition of $20 \mu \mathrm{L}$ of 4-NPA as substrate, prepared in ethanol at the final concentration of $0.7 \mathrm{mM}$ at $25^{\circ} \mathrm{C}$ for $30 \mathrm{~min}$ with regular intervals of $1 \mathrm{~min}$, by using spectrophotometer (xMark ${ }^{\mathrm{TM}}$ Microplate, Bio-Rad, Hercules, CA, USA). HEPES-tris was used as a buffer for the reaction at the final concentration of $20 \mathrm{mM}$ at $\mathrm{pH} 7.4$. 


\subsection{Molecular Docking}

Docking was conducted on Molecular Operating Environment [45] using X-ray crystal structure of human carbonic anhydrase II complexed with acetazolamide (PDB code: 3HS4, resolution: $1.10 \AA$ ) [62]. The docking performance of MOE was tested previously [36,44] by re-docking experiment which shows that MOE is efficient in docking of CA-II inhibitors. In the re-docking, the X-ray conformation of acetazolamide was re-docked at its cognate binding site, where it was docked with $\mathrm{RMSD}=0.61 \AA$. The re-docked conformation is shown in Figure S37. The protein file was prepared for docking by QuickPrep module of MOE which adds missing hydrogen atoms on residues and calculate partial charges using pre-defined force field (we applied Amber10:EHT force field). The two-dimensional (2D-) structures of ligands were prepared by ChemDraw, later converted into 3D-form by MOE using WASH module of MOE which adds hydrogen atoms and partial charges on ligands. Subsequently, the 3D-structure of each compound was minimized until the gradient was reached to $0.1 \mathrm{RMS} \mathrm{kcal} / \mathrm{mol} / \AA$. After the preparation of protein and ligand files, docking was performed by Triangle Matcher docking algorithm and London dG scoring function. Thirty docked conformation of each ligand was saved, and the best docked orientation was selected based on the docking score and binding interactions. The pharmacokinetic profile of the active hits was predicted through SwissADME server using BOILED-Egg model $[61,63]$.

\section{Conclusions}

In summary, a series of twelve new 3-phenyl- $\beta$-alanine 1,3,4-oxadiazoles $4 \mathbf{a}-1$ have been synthesized and CA-II were performed in vitro. From all derivatives, compounds 4a $(12.1 \mu \mathrm{M})$ and $4 \mathbf{c}(13.8 \mu \mathrm{M})$ exhibited the most potent activity against CA-II enzyme. In addition, structure-activity relationship of the active compounds has been established. When the results were compared, it was observed that these molecules show more effective inhibition than the standard inhibitor. Based on molecular docking strategy, we observed the mode of binding interaction of the active hits with the active site residues of CA-II, which suggests that the compounds mainly interact with the Thr199 and Thr200, thus inhibit the activity of CA-II. Based on these results, we suggest that these molecules can be used against CA-II related diseases.

Supplementary Materials: The following supporting information can be downloaded, Figures S1-S36: ${ }^{1} \mathrm{H}-\left(\mathrm{CDCl}_{3}, 600 \mathrm{MHz}\right),{ }^{13} \mathrm{C}-\mathrm{NMR}$ and HRESIMS of the compounds 4a-1, Figure S37: The re-docked orientation of acetazolamide.

Author Contributions: K.R. synthesized the compounds. N.U.R. performed structural elucidation and wrote original draft of the manuscript. A.K. and M.K., performed carbonic anhydrase II inhibition. S.A.H. conducted in silico studies. A.A.-H. supervised the project and assisted in reviewing and editing the manuscript. All authors have read and agreed to the published version of the manuscript.

Funding: The authors are thankful to The Oman Research Council (TRC) through the funded Research Grant Program (BFP/RGP/CBS/21/002).

Institutional Review Board Statement: Not applicable.

Informed Consent Statement: Not applicable.

Data Availability Statement: The spectroscopic data is available in the supporting information to the researchers.

Acknowledgments: The authors are thankful to the University of Nizwa for the generous support to this project. We are also grateful to the analytical and technical staffs of the University for assistance.

Conflicts of Interest: The authors declare no conflict of interest.

Sample Availability: The data presented in this study is available in the Supplementary Material. 


\section{References}

1. Payaz, D.Ü.; Küçükbay, F.Z.; Küçükbay, H.; Angeli, A.; Supuran, C.T. Synthesis carbonic anhydrase enzyme inhibition and antioxidant activity of novel benzothiazole derivatives incorporating glycine, methionine, alanine, and phenylalanine moieties. $J$. Enzym. Inhib. Med. Chem. 2019, 1, 343-349. [CrossRef] [PubMed]

2. Akocak, S.; Lolak, N.; Nocentini, A.; Karakoc, G.; Tufan, A.; Supuran, C.T. Synthesis and biological evaluation of novel aromatic and heterocyclic bis-sulfonamide Schiff bases as carbonic anhydrase I, II, VII and IX inhibitors. Bioorganic Med. Chem. 2017, 12, 3093-3097. [CrossRef] [PubMed]

3. D'Ascenzio, M.; Guglielmi, P.; Carradori, S.; Secci, D.; Florio, R.; Mollica, A.; Ceruso, M.; Akdemir, A.; Sobolev, A.P.; Supuran, C.T. Open saccharin-based secondary sulfonamides as potent and selective inhibitors of cancer-related carbonic anhydrase IX and XII isoforms. J. Enzym. Inhib. Med. Chem. 2017, 1, 51-59. [CrossRef] [PubMed]

4. Gokcen, T.; Gulcin, I.; Ozturk, T.; Goren, A.C. A class of sulfonamides as carbonic anhydrase I and II inhibitors. J. Enzym. Inhib. Med. Chem. 2016, 2, 180-188. [CrossRef] [PubMed]

5. Gul, H.I.; Mete, E.; Taslimi, P.; Gulcin, I.; Supuran, C.T. Synthesis, carbonic anhydrase I and II inhibition studies of the 1,3,5trisubstituted-pyrazolines. J. Enzym. Inhib. Med. Chem. 2017, 1, 189-192. [CrossRef] [PubMed]

6. Ibrahim, D.A.; Lasheen, D.S.; Zaky, M.Y.; Ibrahim, A.W.; Vullo, D.; Ceruso, M.; Supuran, C.T.; Abou El Ella, D.A. Design and synthesis of benzothiazole-6-sulfonamides acting as highly potent inhibitors of carbonic anhydrase isoforms I, II, IX and XII. Bioorganic Med. Chem. 2015, 15, 4989-4999. [CrossRef] [PubMed]

7. Sağlık, B.N.; Cevik, U.A.; Osmaniye, D.; Levent, S.; Çavuşoğlu, B.K.; Demir, Y.; Ilgın, S.; Özkay, Y.; Koparal, A.S.; Beydemir, S. Synthesis, molecular docking analysis and carbonic anhydrase I-II inhibitory evaluation of new sulfonamide derivatives. Bioorganic Chem. 2019, 91, 103153. [CrossRef]

8. Angeli, A.; Ferraroni, M.; Supuran, C.T. Famotidine, an antiulcer agent, strongly inhibits Helicobacter pylori and human carbonic anhydrases. ACS Med. Chem. Lett. 2018, 10, 1035-1038. [CrossRef]

9. Khloya, P.; Celik, G.; Vullo, D.; Supuran, C.T.; Sharma, P.K. 4-Functionalized 1,3-diarylpyrazoles bearing benzenesulfonamide moiety as selective potent inhibitors of the tumor associated carbonic anhydrase isoforms IX and XII. Eur. J. Med. Chem. 2014, 76, 284-290. [CrossRef]

10. Aggarwal, M.; Boone, C.D.; Kondeti, B.; McKenna, R. Structural annotation of human carbonic anhydrases. J. Enzym. Inhib. Med. Chem. 2013, 2, 267-277. [CrossRef]

11. Supuran, C.T. Carbonic anhydrases-an overview. Curr. Pharm. Des. 2008, 7, 603-614. [CrossRef] [PubMed]

12. Lee, A.H.; Tannock, I.F. Heterogeneity of intracellular $\mathrm{pH}$ and of mechanisms that regulate intracellular $\mathrm{pH}$ in populations of cultured cells. Cancer Res. 1998, 9, 1901-1908.

13. Montcourrier, P.; Silver, I.; Farnoud, R.; Bird, I.; Rochefort, H. Breast cancer cells have a high capacity to acidify extracellular milieu by a dual mechanism. Clin. Exp. Metastasis 1997, 4, 382-392. [CrossRef]

14. Webb, S.; Sherratt, J.; Fish, R. Mathematical modelling of tumor acidity: Regulation of intracellular pH. J. Theor. Biol. 1999, 2, 237-250. [CrossRef] [PubMed]

15. Frazier, M.L.; Lilly, B.J.; Wu, E.F.; Ota, T.; Hewett-Emmett, D. Carbonic anhydrase II gene expression in cell lines from human pancreatic adenocarcinoma. Pancreas 1990, 5, 507-514. [CrossRef]

16. Parkkila, A.-K.; Herva, R.; Parkkila, S.; Rajaniemi, H. Immunohistochemical demonstration of human carbonic anhydrase isoenzyme II in brain tumours. Histochem. J. 1995, 12, 974-982. [CrossRef]

17. Parkkila, S.; Rajaniemi, H.; Parkkila, A.-K.; Kivelä, J.; Waheed, A.; Pastoreková, S.; Pastorek, J.; Sly, W.S. Carbonic anhydrase inhibitor suppresses invasion of renal cancer cells in vitro. Proc. Natl. Acad. Sci. USA 2000, 5, 2220-2224. [CrossRef]

18. Achal, V.; Pan, X. Characterization of urease and carbonic anhydrase producing bacteria and their role in calcite precipitation. Curr. Microbiol. 2011, 3, 894-902. [CrossRef]

19. Şentürk, M.; Gülçin, İ.; Beydemir, Ş.; Küfrevioğlu, Ö.İ.; Supuran, C.T. In vitro inhibition of human carbonic anhydrase I and II isozymes with natural phenolic compounds. Chem. Biol. Drug Des. 2011, 6, 494-499. [CrossRef]

20. Supuran, C.T. Structure and function of carbonic anhydrases. Biochem. J. 2016, 14, 2023-2032. [CrossRef]

21. Desai, N.; Dodiya, A.M.; Rajpara, K.M.; Rupala, Y.M. Synthesis and antimicrobial screening of 1,3,4-oxadiazole and clubbed thiophene derivatives. J. Saudi Chem. Soc. 2014, 3, 255-261. [CrossRef]

22. Wani, M.Y.; Ahmad, A.; Shiekh, R.A.; Al-Ghamdi, K.J.; Sobral, A.J. Imidazole clubbed 1,3,4-oxadiazole derivatives as potential antifungal agents. Bioorganic Med. Chem. 2015, 15, 4172-4180. [CrossRef] [PubMed]

23. Dewangan, D.; Verma, V.S.; Nakhate, K.T.; Tripathi, D.K.; Kashyap, P.; Dhongade, H. Synthesis, characterization, and screening for analgesic and anti-inflammatory activities of new 1,3,4-oxadiazole derivatives linked to quinazolin-4-one ring. Med. Chem. Res. 2016, 10, 2143-2154. [CrossRef]

24. Singh, A.K.; Lohani, M.; Parthsarthy, R. Synthesis, characterization and anti-inflammatory activity of some 1,3,4-oxadiazole derivatives. Iran. J. Pharm. Res. IJPR 2013, 2, 319.

25. Gan, X.; Hu, D.; Chen, Z.; Wang, Y.; Song, B. Synthesis and antiviral evaluation of novel 1,3,4-oxadiazole/thiadiazole-chalcone conjugates. Bioorganic Med. Chem. Lett. 2017, 18, 4298-4301. [CrossRef] [PubMed]

26. Abdo, N.Y.M.; Kamel, M.M. Synthesis and anticancer evaluation of 1,3,4-oxadiazoles, 1,3,4-thiadiazoles, 1,2,4-triazoles and Mannich bases. Chem. Pharm. Bull. 2015, 5, 369-376. [CrossRef] 
27. Schlecker, R.; Thieme, P.C. The synthesis of antihypertensive 3-(1,3,4-oxadiazol-2-yl) phenoxypropanolahines. Tetrahedron 1988, 11, 3289-3294. [CrossRef]

28. Tabatabai, S.A.; Lashkari, S.B.; Zarrindast, M.R.; Gholibeikian, M.; Shafiee, A. Design, synthesis and anticonvulsant activity of 2-(2-phenoxy) phenyl-1,3,4-oxadiazole derivatives. Iran. J. Pharm. Res. IJPR 2013, 12, 105.

29. Shyma, P.; Balakrishna, K.; Peethambar, K.; Vijesh, M. Synthesis, characterization, antidiabetic and antioxidant activity of 1,3,4-oxadiazole derivatives bearing 6-methyl pyridine moiety. Der Pharma. Chem. 2015, 12, 137-145.

30. Musmade, D.; Pattan, S.; Manjunath, S.Y. Oxadiazole a nucleus with versatile biological behavior. Int. J. Pharm. Chem. 2015, 1, 11-20.

31. Sengupta, P.; Mal, M.; Mandal, S.; Singh, J.; Maity, T.K. Evaluation of antibacterial and antifungal activity of some 1,3,4 oxadiazoles. Iran. J. Pharmacol. Ther. 2008, 2, 165-167.

32. Glomb, T.; Szymankiewicz, K.; Światek, P. Anti-cancer activity of derivatives of 1,3,4-oxadiazole. Molecules 2018, $12,3361$. [CrossRef] [PubMed]

33. Abd-Ellah, H.S.; Abdel-Aziz, M.; Shoman, M.E.; Beshr, E.A.; Kaoud, T.; Ahmed, A.-S.F. New 1,3,4-oxadiazole/oxime hybrids: Design, synthesis, anti-inflammatory, COX inhibitory activities and ulcerogenic liability. Bioorganic Chem. 2017, 74, 15-29. [CrossRef] [PubMed]

34. Tantray, M.A.; Khan, I.; Hamid, H.; Alam, M.S.; Dhulap, A.; Kalam, A. Synthesis of benzimidazole-linked-1,3,4-oxadiazole carboxamides as GSK-3 $\beta$ inhibitors with in vivo antidepressant activity. Bioorganic Chem. 2018, 77, 393-401. [CrossRef]

35. Yadagiri, B.; Gurrala, S.; Bantu, R.; Nagarapu, L.; Polepalli, S.; Srujana, G.; Jain, N. Synthesis and evaluation of benzosuberone embedded with 1,3,4-oxadiazole, 1,3,4-thiadiazole and 1,2,4-triazole moieties as new potential anti proliferative agents. Bioorganic Med. Chem. Lett. 2015, 10, 2220-2224. [CrossRef]

36. Manjunatha, K.; Poojary, B.; Lobo, P.L.; Fernandes, J.; Kumari, N.S. Synthesis and biological evaluation of some 1,3,4-oxadiazole derivatives. Eur. J. Med. Chem. 2010, 11, 5225-5233. [CrossRef]

37. Hajimahdi, Z.; Zarghi, A.; Zabihollahi, R.; Aghasadeghi, M. Synthesis, biological evaluation, and molecular modeling studies of new 1,3,4-oxadiazole-and 1,3,4-thiadiazole-substituted 4-oxo-4 H-pyrido [1, 2-a] pyrimidines as anti-HIV-1 agents. Med. Chem. Res. 2013, 5, 2467-2475. [CrossRef]

38. Xu, W.-M.; Li, S.-Z.; He, M.; Yang, S.; Li, X.-Y.; Li, P. Synthesis and bioactivities of novel thioether/sulfone derivatives containing 1,2,3-thiadiazole and 1,3,4-oxadiazole/thiadiazole moiety. Bioorganic Med. Chem. Lett. 2013, 21, 5821-5824. [CrossRef]

39. Vats, L.; Sharma, V.; Angeli, A.; Kumar, R.; Supuran, C.T.; Sharma, P.K. Synthesis of novel 4-functionalized 1,5-diaryl-1,2,3triazoles containing benzenesulfonamide moiety as carbonic anhydrase I, II, IV and IX inhibitors. Eur. J. Med. Chem. 2018, 150, 678-686. [CrossRef]

40. Sharma, V.; Kumar, R.; Bua, S.; Supuran, C.T.; Sharma, P.K. Synthesis of novel benzenesulfonamide bearing 1,2,3-triazole linked hydroxy-trifluoromethylpyrazolines and hydrazones as selective carbonic anhydrase isoforms IX and XII inhibitors. Bioorganic Chem. 2019, 85, 198-208. [CrossRef]

41. Kumar, R.; Vats, L.; Bua, S.; Supuran, C.T.; Sharma, P.K. Design and synthesis of novel benzenesulfonamide containing 1,2,3triazoles as potent human carbonic anhydrase isoforms I, II, IV and IX inhibitors. Eur. J. Med. Chem. 2018, 155, 545-551. [CrossRef] [PubMed]

42. Kumar, R.; Sharma, V.; Bua, S.; Supuran, C.T.; Sharma, P.K. Synthesis and biological evaluation of benzenesulphonamide-bearing 1,4,5-trisubstituted-1,2,3-triazoles possessing human carbonic anhydrase I, II, IV, and IX inhibitory activity. J. Enzym. Inhib. Med. Chem. 2017, 1, 1187-1194. [CrossRef] [PubMed]

43. Bianco, G.; Meleddu, R.; Distinto, S.; Cottiglia, F.; Gaspari, M.; Melis, C.; Corona, A.; Angius, R.; Angeli, A.; Taverna, D. N-Acylbenzenesulfonamide dihydro-1,3,4-oxadiazole hybrids: Seeking selectivity toward carbonic anhydrase isoforms. ACS Med. Chem. Lett. 2017, 8, 792-796. [CrossRef] [PubMed]

44. Sharma, V.; Kumar, R.; Angeli, A.; Supuran, C.T.; Sharma, P.K. Tail approach synthesis of novel benzenesulfonamides incorporating 1,3,4-oxadiazole hybrids as potent inhibitor of carbonic anhydrase I, II, IX, and XII isoenzymes. Eur. J. Med. Chem. 2020, 193, 112219. [CrossRef]

45. Swain, B.; Singh, P.; Angeli, A.; Aashritha, K.; Nagesh, N.; Supuran, C.T.; Arifuddin, M. 3-Functionalised benzenesulphonamide based 1,3,4-oxadiazoles as selective carbonic anhydrase XIII inhibitors: Design, synthesis and biological evaluation. Bioorganic Med. Chem. Lett. 2021, 37, 127856. [CrossRef]

46. Avula, S.K.; Rehman, N.U.; Khan, M.; Halim, S.A.; Khan, A.; Rafiq, K.; Csuk, R.; Das, B.; Al-Harrasi, A. New synthetic 1H-1,2,3triazole derivatives of 3-O-acetyl- $\beta$-boswellic acid and 3-O-acetyl-11-keto- $\beta$-boswellic acid from Boswellia sacra inhibit carbonic anhydrase II in vitro. Med. Chem. Res. 2021, 6, 1185-1198. [CrossRef]

47. Avula, S.K.; Khan, M.; Halim, S.A.; Khan, A.; Al-Riyami, S.A.; Csuk, R.; Das, B.; Al-Harrasi, A. Synthesis of new 1H-1,2,3-triazole analogs in aqueous medium via "click" chemistry: A novel class of potential carbonic anhydrase-II inhibitors. Front. Chem. 2021, 9, 642614. [CrossRef]

48. von Neubeck, B.; Gondi, G.; Riganti, C.; Pan, C.; Parra Damas, A.; Scherb, H.; Ertürk, A.; Zeidler, R. An inhibitory antibody targeting carbonic anhydrase XII abrogates chemoresistance and significantly reduces lung metastases in an orthotopic breast cancer model in vivo. Int. J. Cancer 2018, 8, 2065-2075. [CrossRef]

49. Angeli, A.; Trallori, E.; Carta, F.; Di Cesare Mannelli, L.; Ghelardini, C.; Supuran, C.T. Heterocoumarins are selective carbonic anhydrase IX and XII inhibitors with cytotoxic effects against cancer cells lines. ACS Med. Chem. Lett. 2018, 9, 947-951. [CrossRef] 
50. Vullo, D.; Innocenti, A.; Nishimori, I.; Pastorek, J.R.; Scozzafava, A.; Pastoreková, S.; Supuran, C.T. Carbonic anhydrase inhibitors. Inhibition of the transmembrane isozyme XII with sulfonamides-a new target for the design of antitumor and antiglaucoma drugs? Bioorganic Med. Chem. Lett. 2005, 4, 963-969. [CrossRef]

51. Kumar, S.; Rulhania, S.; Jaswal, S.; Monga, V. Recent advances in the medicinal chemistry of carbonic anhydrase inhibitors. Eur. J. Med. Chem. 2021, 209, 112923. [CrossRef] [PubMed]

52. Rafiq, K.; Khan, M.; Muhammed, N.; Khan, A.; Rehman, N.U.; Al-Yahyaei, B.E.M.; Khiat, M.; Halim, S.A.; Shah, Z.; Csuk, R. New amino acid clubbed Schiff bases inhibit carbonic anhydrase II, $\alpha$-glucosidase, and urease enzymes: In silico and in vitro. Med. Chem. Res. 2021, 3, 712-728. [CrossRef]

53. Ur Rehman, N.; Halim, S.A.; Khan, M.; Hussain, H.; Yar Khan, H.; Khan, A.; Abbas, G.; Rafiq, K.; Al-Harrasi, A. Antiproliferative and carbonic anhydrase II inhibitory potential of chemical constituents from Lycium shawii and aloe vera: Evidence from in silico target fishing and in vitro testing. Pharmaceuticals 2020, 5, 94. [CrossRef] [PubMed]

54. Banerjee, A.K.; Vera, W.; Mora, H.; Laya, M.S.; Bedoya, L.; Cabrera, E.V. Iodine in organic synthesis. J. Sci. Ind. Res. 2006, 65, 299-308. [CrossRef]

55. Ren, Y.-M.; Cai, C.; Yang, R.-C. Molecular iodine-catalyzed multicomponent reactions: An efficient catalyst for organic synthesis. RSC Adv. 2013, 20, 7182-7204. [CrossRef]

56. Gao, W.-C.; Jiang, S.; Wang, R.-L.; Zhang, C. Iodine-mediated intramolecular amination of ketones: The synthesis of 2-acylindoles and 2-acylindolines by tuning N-protecting groups. Chem. Commun. 2013, 43, 4890-4892. [CrossRef] [PubMed]

57. He, Z.; Li, H.; Li, Z. Iodine-Mediated Synthesis of 3 H-Indoles via Intramolecular Cyclization of Enamines. J. Org. Chem. 2010, 13, 4636-4639. [CrossRef]

58. Jiang, H.; Huang, H.; Cao, H.; Qi, C. TBHP/I2-mediated domino oxidative cyclization for one-pot synthesis of polysubstituted oxazoles. Org. Lett. 2010, 23, 5561-5563. [CrossRef]

59. Wan, C.; Gao, L.; Wang, Q.; Zhang, J.; Wang, Z. Simple and efficient preparation of 2,5-disubstituted oxazoles via a metal-freecatalyzed cascade cyclization. Org. Lett. 2010, 17, 3902-3905. [CrossRef]

60. Wan, C.; Zhang, J.; Wang, S.; Fan, J.; Wang, Z. Facile synthesis of polysubstituted oxazoles via a copper-catalyzed tandem oxidative cyclization. Org. Lett. 2010, 10, 2338-2341. [CrossRef]

61. Daina, A.; Michielin, O.; Zoete, V. SwissADME: A free web tool to evaluate pharmacokinetics, drug-likeness and medicinal chemistry friendliness of small molecules. Sci. Rep. 2017, 1, 42717. [CrossRef] [PubMed]

62. Sippel, K.H.; Robbins, A.H.; Domsic, J.; Genis, C.; Agbandje-McKenna, M.; McKenna, R. High-resolution structure of human carbonic anhydrase II complexed with acetazolamide reveals insights into inhibitor drug design. Acta Crystallogr. Sect. F Struct. Biol. Cryst. Commun. 2009, 10, 992-995. [CrossRef] [PubMed]

63. Daina, A.; Zoete, V. A boiled-egg to predict gastrointestinal absorption and brain penetration of small molecules. ChemMedChem 2016, 11, 1117. [CrossRef] [PubMed] 